\title{
Essential Tremor and Alexithymia
}

Esansiyel Tremor ve Aleksitimi

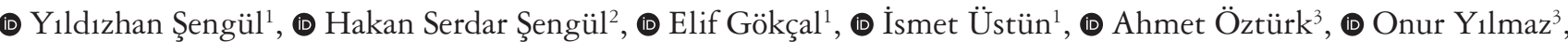 \\ (1) Gülsen Babacan Yıldız
}

'Bezmialem Vakif University Faculty of Medicine Hospital, Department of Neurology, Istanbul, Turkey ${ }^{2}$ Istanbul Gaziosmanpasa Taksim Ilkyardim Training and Research Hospital, Clinic of Neuropsychology, Istanbul, Turkey

${ }^{3}$ Bezmialem Vakif University Faculty of Medicine Hospital, Department of Psychiatry, Istanbul, Turkey

\begin{abstract}
Objective: Essential tremor (ET) is the most common cause of tremor. We know that this disease, which was presumed to be monosymptomatic until recently, may be accompanied by motor findings and a series of non-motor findings other than action tremor. Alexithymia can be defined as not being able to name emotions, express emotions, distinguish emotions from each other, or living without being aware of one's own emotions. The aim of our study was to evaluate alexithymia in patients with ET.

Materials and Methods: Forty-four patients with ET (mean age $=38.22 \pm 18.05$ years) and 46 control subjects (mean age $=37.17 \pm 10.68$ years) were included in the study. The Fahn-Tolosa-Marin Tremor Rating Scale was used for the patient group and the Toronto Alexithymia Scale (TAS), Beck Depression Inventory and Beck Anxiety Inventory were applied to both groups.

Results: The mean TAS was 49.16 \pm 8.94 in the patient group and $42.34 \pm 6.27$ in the control group $(\mathrm{p}<0.001)$. The comparison between subgroup scores showed that the patient group had difficulty in recognizing their feelings and increase in externally-oriented thinking.

Conclusion: Our study has shown that alexithymia may be present in patients with ET. Studies involving larger patient groups and imaging in this respect will be useful in illuminating the place of alexithymia in the non-motor symptom spectrum of the disease.
\end{abstract}

Keywords: Essential tremor, alexithymia, non-motor symptoms

Öz

Amaç: Esansiyel tremor (ET) en sık görülen tremor nedenidir. Çok yakın bir zamana kadar monosemptomatik olduğu öngörülen bu hastalığa günümüzde aksiyon tremoru dışında motor ve bir dizi motor dışı bulguların da eşlik edebileceğini artık biliyoruz. Aleksitimi ise duyguları isimlendirememek, ifade edememek, duygularını birbirinden ayrıştıramamak veya duygularını farkında olmaksızın yaşamak şeklinde özetlenebilir. Çalışmamızda ET hastalarında aleksitiminin değerlendirilmesi amaçlanmıştır.

Gereç ve Yöntem: Çalışmamıza 44 ET hastası (yaş ortalaması=38,22 $\pm 18,05$ yıl) ve 46 kontrol birey (yaş ortalaması=37,17 $\pm 10,68$ yıl) alındı. Hasta grubuna Fahn-Tolosa-Marin Tremor Değerlendirme Ölçeği ve her iki gruba Toronto Aleksitimi Ölçeği (TAÖ), Beck Depresyon Ölçeği, Beck Anksiyete Ölçeği uygulandı.

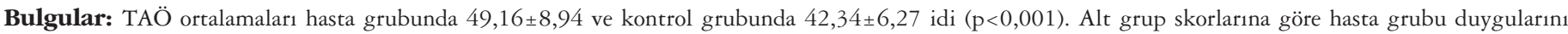
tanımada zorluk ve dışa dönük düşüncede artış yaşıyordu. Depresif belirtiler ve anksiyete düzeyleri hasta grubunda fazlaydı.

Sonuç: Çalışmamız ET hastalarında aleksitiminin olabileceğini göstermiştir. Bu konuda daha geniş hasta gruplarıyla yapılacak ve görüntülemenin de dahil edildiği çalışmaların, aleksitiminin hastalığın motor dışı belirti yelpazesindeki yerinin aydınlatılmasında faydalı olacağı kanaatindeyiz.

Anahtar Kelimeler: Esansiyel tremor, aleksitimi, motor dışı belirtiler

\section{Introduction}

Essential tremor (ET) is the most frequently seen movement disorder and also is the most common cause of tremor in adults (1). Its prevalence in all age groups is $0.9 \%$, whereas it is $4.6 \%$ in people aged over 65 years (2). Its prevalence was found as $4 \%$ in a study from Turkey (3). ET is a kinetic and/or postural tremor with a peak frequency of $8-12 \mathrm{~Hz}$ that occurs in hands and arms during voluntary movement. The other parts of the body that are most commonly affected by tremor are head, vocal cords, trunk,

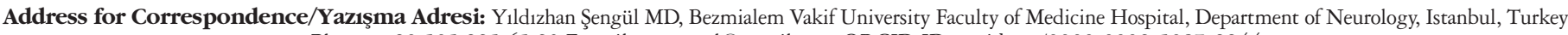
Phone: +90 5059256523 E-mail: yysengul@gmail.com ORCID ID: orcid.org/0000-0002-5087-9944

Received/Geliş Tarihi: 31.12.2017 Accepted/Kabul Tarihi: 05.02.2018

${ }^{\oplus}$ Copyright 2018 by Turkish Neurological Society

Turkish Journal of Neurology published by Galenos Publishing House. 
legs, and face, respectively. The disease was thought to be a monosymptomatic, benign and pure motor disease until recently, but now this definition is changing (4). There are studies showing that tremor types other than action tremor as well as cerebellar findings, mild bradykinesia, hearing loss, and ocular findings may be seen in $\operatorname{ET}(5,6,7,8,9,10,11,12,13)$. Non-motor findings besides motor findings now feature in the symptom spectrum of ET. The most studied non-motor symptoms are cognitive impairment, personality and mood features, depression, anxiety, sleep disorders, and fatigue (14). Coexistence of motor and non-motor findings, disease progression in time, and increase in prevalence with age suggest a neurodegenerative nature for ET, which has been supported recently by neuroimaging and autopsy studies. The frame of it is shifting from an olivary model to a cerebellar model, and the pathology of ET is being associated with loss of Purkinje cells (15). Alexithymia can be described as inability to say something about emotions; the term was first used by Sifneos (1972) to describe difficulty in expressing feelings in patients with psychosomatic disorders (16). Alexithymia can be summarized as being unable to name and explain feelings, to distinguish feelings from each other or living without being aware of own feelings. There are many studies about neuroanatomy of alexithymia, which showed a relationship between alexithymia and the anterior cingulate cortex, prefrontal cortex, striato-thalamo-cortical pathway, corpus callosum, and especially the frontotemporal areas, orbitofrontal cortex, amygdala, and insula in the right hemisphere (17). The cerebellum integrates various motor pathways related with cognitive and emotional processing via its connections with the limbic system, prefrontal cortex, and temporoparietal area. A study showed that alexithymia was related with reduced cerebellar activity (18). We aimed to investigate alexithymia and its features in patients with ET in this study. To our knowledge, there is no study in the literature about ET and alexithymia. The evaluation of alexithymia will be useful in terms of recognizing the broad symptom spectrum of the disease.

\section{Materials and Methods}

Patients who were admitted to the general neurology and movement disorders outpatient clinic and diagnosed as having ET according to the Washington Heights-Inwood Genetic Study of ET Diagnostic Criteria were included in the study (19). The control group comprised of individuals who met the exclusion criteria for the study group and who did not have tremor or family history of tremor. The approval was obtained from Ethics Committee of Hospital Bezmialem Vakif University (approval no: 16/2, date: 19.08.2017). Routine hemogram, and serum biochemical and hormonal investigations were performed at the beginning of the study. Patients who were using medications or had abnormalities in blood tests that could cause tremor and patients who had a history of excessive alcohol or coffee consumption were excluded from the study. Kayser-Fleischer ring was examined to exclude Wilson's disease. Patients who were still followed by a psychiatrist and were using psychiatric drugs were excluded from the study because psychiatric diseases and drugs might cause tremor. Sociodemographic features of both groups were recorded. The duration of the disease and family history for ET were noted was evaluated using the Fahn-Tolosa-Marin Clinical Tremor Rating Scale (FTM-TRS). In the study group the Toronto Alexithymia Scale (TAS), Beck Depression Inventory (BDI) and Beck Anxiety Inventory (BAI) were performed in both groups.

\section{Toronto Alexithymia Scale}

The TAS consists of 20 items and each item is scored from 1 to 5. Some items are scored reversely. It comprises three subgroups: Difficulty in recognizing feelings, difficulty in expressing feelings, and externally-oriented thinking (20). Güleç et al. (21) performed the validity and reliability study of TAS in Turkish. Scoring is as follows: <50 points: No alexithymia, 51-60 points: Probable alexithymia, >61 points: Definite alexithymia.

\section{Beck Depression Inventory}

The BDI consists of 21 items. Each item is scored 0-3. High scores mean increased frequency of depressive symptoms; 0-13: Minimal depression, 14-19: Mild depression, 20-28: Moderate depression and 29-63: Severe depression (22).

\section{Beck Anxiety Inventory}

The BAI consists of 21 items. Each item is scored 0-3; 26-63: Severe anxiety, 16-25: Moderate anxiety and 8-15: Mild anxiety (23).

\section{Statistical Analysis}

SPSS 21.0 was used for statistical analysis. Descriptive statistical methods were used to analyze the data; frequency, percentage, mean, and standard deviation were used to determine the demographic characteristics of the patients. The data were analyzed using the independent samples $t$ test. $\mathrm{P}$ values less than 0.05 were considered significant.

\section{Results}

Forty-four patients with ET and 46 control individuals were included in the study. The mean ages of the patient and control group ere $38.22 \pm 18.05$ years and $37.17 \pm 10.68$ years, respectively. Sociodemographic features such as male-female distribution, educational and marital status were similar in both groups and are summarized in Table 1 . The mean duration of disease was $8.68 \pm 9.62$ years. The mean score of FTM-TRS was 21.38 4.25 . Thirty-three of 44 patients $(75 \%$ ) had a positive family history for ET. The mean score of TAS was $49.16 \pm 8.94$ in the study group and $42.34 \pm 6.27$ in the control group $(\mathrm{p}<0.001)$. In the subgroup analysis, the mean score of difficulty in recognizing feelings was $14.81 \pm 5.41$ in the study group and $11.17 \pm 3.57$ in the control group $(\mathrm{p}<0.001)$. The subgroup score of externally-oriented thinking was higher in the study group $(\mathrm{p}<0.001)$. TAS total and subgroup scores are compared between groups in Table 2 . The significant difference between two groups in terms of the mean TAS scores was also preserved after the exclusion of patients and controls with moderate and high depression levels $(47.02 \pm 27.75$ vs. $42.17 \pm 6.23, p=0.003)$. In the subgroup analysis, after the exclusion of patients and controls with moderate and high depression levels, the significant differences between the groups in terms of difficulty in recognizing feelings (13.72 \pm 4.51 vs. $11.04 \pm 3.50, \mathrm{p}=0.004)$ and increase in externally-oriented thinking $(22.30 \pm 3.93$ vs. $19.73 \pm 3.63, \mathrm{p}=0.003)$ were still preserved. There 
were $5(14.6 \%)$ patients with definite alexithymia in the study group, whereas there was nobody with definite alexithymia in the control group. There were 13 patients $(30.2 \%)$ with probable alexithymia in the study group and $4(8.7 \%)$ in the control group (Table 3). The patients had higher scores in BDI and BAI compared to the control group $(\mathrm{p}=0.024$ and $\mathrm{p}<0.001$, respectively).

\begin{tabular}{|lll|}
\hline \multicolumn{3}{|c|}{ Table 1. Demographic features } \\
Age & Patients $(\mathrm{n}=44)$ & Controls $(\mathrm{n}=46)$ \\
Sex & $38.22 \pm 18.05$ & $37.17 \pm 10.68$ \\
Male & $12(27.3 \%)$ & $10(21.7 \%)$ \\
Female & $32(72.7 \%)$ & $36(78.3 \%)$ \\
Marital status & & \\
Single & $19(43.2 \%)$ & $13(28.3 \%)$ \\
Married & $22(50 \%)$ & $32(69.6 \%)$ \\
Divorced or widowed & $3(6.8 \%)$ & $1(2.2 \%)$ \\
Educational status & & \\
Literate & $1(2.3 \%)$ & $3(6.5 \%)$ \\
Primary school & $11(25 \%)$ & $17(37 \%)$ \\
Middle school & $4(9.1 \%)$ & $5(10.9 \%)$ \\
Secondary school & $21(47.7 \%)$ & $9(19.6 \%)$ \\
High school & $7(15.9 \%)$ & $12(26.1 \%)$ \\
\hline
\end{tabular}

Table 2. The distribution of subgroup and total scores in the Toronto Alexithymia Scale, and the comparison of the mean scores of Beck Anxiety Inventory and Beck Depression Inventory

\begin{tabular}{lll} 
& Patients $(\mathrm{n}=44)$ & Controls $(\mathrm{n}=46)$ \\
Recognizing feelings & $14.81 \pm 5.41$ & $11.17 \pm 3.57$ \\
Expressing feelings & $12.25 \pm 3.07$ & $11.47 \pm 3.18$ \\
$\begin{array}{l}\text { Externally-oriented } \\
\text { thinking }\end{array}$ & $22.69 \pm 4.18$ & $19.69 \pm 3.58$ \\
Total TAS score & $49.16 \pm 8.94$ & $42.34 \pm 6.27$ \\
BAI score & $17.04 \pm 11.22$ & $4.04 \pm 6.72$ \\
BDI score & $11.07 \pm 8.39$ & $7.06 \pm 7.84$ \\
$\begin{array}{l}\text { TAS: Toronto Alexithymia } \\
\text { Depression Inventory }\end{array}$ & Scale, BAI: Beck Anxiety & Inventory, BDI: Beck \\
\hline
\end{tabular}

Table 3. Distribution of patients and controls according to the Toronto Alexithymia Scale

\begin{tabular}{|lll|}
\hline & Patients $(\mathrm{n}=44)$ & Controls $(\mathrm{n}=46)$ \\
No alexithymia & $25(58.1 \%)$ & $42(91.3 \%)$ \\
Probable alexithymia & $13(30.2 \%)$ & $4(8.7 \%)$ \\
Definite alexithymia & $5(11.6 \%)$ & 0 \\
\hline
\end{tabular}

\section{Discussion}

With the findings of recent research, the symptom spectrum of ET has expanded and its classical definition as a mono-symptomatic disease is no longer valid. Besides motor symptoms, non-motor symptoms have also become increasingly well recognized $(24,25)$. We aimed to search for the coexistence of alexithymia and ET in this study. The number of patients with definite and probable alexithymia and the total alexithymia scores were significantly higher in the study group compared with the control group. Subgroup analysis showed that the patients in the study group had more problems in expressing feelings and increase in externallyoriented thinking compared with the control group. When the patients and control individuals with depression were excluded (as depression and alexithymia may coexist), the significant difference between groups was still preserved. To our knowledge, this is the first study to investigate the coexistence of ET and alexithymia. Increased depression and anxiety and specific personality traits in patients with ET have previously been studied (14). Harm avoidance is more prevalent in patients with ET (26). Also, studies showed that patients with ET were more pessimistic, anxious, and shy, and were less aggressive, gentle, and thoughtful $(27,28)$. Our findings suggest that alexithymia can be a specific neuropsychiatric symptom of the disease, besides others. The most frequent nonmotor symptom of ET is cognitive impairment. First, frontal lobe dysfunction was reported (29), and then impairments in verbal fluency, naming, verbal memory and working memory were shown in other studies $(30,31,32,33)$. A study in young ET patients from Turkey including by neuroimaging data showed impairments in visuo-spatial and executive functions (34). Depression and anxiety are other non-motor disturbances that contribute to ET and worsen quality of life. According to new perspectives, depression is thought to be a n outcome of the underlying disease mechanism rather than a consequence of the disease itself $(35,36,37)$. Autopsy studies showed Lewy bodies in the locus coeruleus of ET patients, which suggested that these patients could have sleep disorders, and then studies found a correlation between short sleep duration and ET $(38,39)$.

\section{Study Limitations}

There are some limitations to the study. The number of patients in our study was small. The tests were filled out by the patients themselves under the supervision of a psychiatrist. A detailed neuropsychiatric evaluation was not performed. We could not find any clues about the neuroanatomical basis for the coexistence of alexithymia and ET due to lack of imaging modalities in this study.

\section{Conclusion}

In our study, we showed that alexithymia and ET may coexist. Studies with larger numbers of patients and supported by neuroimaging data are required to determine the place of alexithymia in the spectrum of non-motor symptoms of ET. Psychiatric evaluations and initiating the appropriate treatment in patients with ET and alexithymia will also have positive impact on the social lives of the patients.

\section{Acknowledgement}

Thanks to Dr. Hulki Forta for his valuable contributions. 


\section{Ethics}

Ethics Committee Approval: The approval was obtained from Ethics Committee of Bezmialem Vakif University (approval no: $16 / 2$, date: 19.08.2017).

Informed Consent: Informed consent was taken from all patients and control individuals included in the study.

Peer-review: Externally peer-reviewed.

\section{Authorship Contributions}

Surgical and Medical Practices: Y.Ş., O.Y., A.Ö., Concept: Y.Ş., G.B.Y., Design: Y.Ş., Data Collection or Processing: Y.Ş., İ.Ü., E.G., Analysis or Interpretation: Y.Ş., H.S.Ş., Literature Search: Y.Ş., E.G., Writing: Y.Ş., H.S.Ş.

Conflict of Interest: No conflict of interest was declared by the authors.

Financial Disclosure: The authors declared that this study received no financial support.

\section{References}

1. Louis ED, Ottman R, Hauser WA. How common is the most common adult movement disorder? estimates of the prevalence of essential tremor throughout the world. Mov Disord 1998;13:5-10.

2. Louis ED, Ferreira JJ. How common is the most common adult movement disorder? Update on the worldwide prevalence of essential tremor. Mov Disord 2010;25:534-541.

3. Doğu O, Sevim S, Camdeviren H, et al. Prevalence of essential tremor: door-to-door neurologic exams in Mersin Province, Turkey. Neurology 2003;61:1804-1806.

4. Benito-León J, Louis ED. Essential tremor: emerging views of a common disorder. Nat Clin Pract Neurol 2006;2:666-678.

5. Chandran V, Pal PK. Essential tremor: beyond the motor features Parkinsonism Relat Disord 2012;18:407-413.

6. Ondo WG, Sutton L, Dat Vuong K, Lai D, Jankovic J. Hearing impairment in essential tremor. Neurology 2003;61:1093-1097.

7. Balaban H, Altuntaş EE, Uysal IO, Sentürk IA, Topaktaş S. Audio-vestibular evaluation in patients with essential tremor. Eur Arch Otorhinolaryngo 2012;269:1577-1581

8. Yilmaz NH, Akbostanci MC, Yilmaz N. Sensorineural Hearing Loss in Nondepressed Essential Tremor Cases and Controls: A Clinical and Audiometric Study. Tremor Other Hyperkinet Mov (N Y) 2015;5:281.

9. Wójcik-Pedziwiatr M, Plinta K, Krzak-Kubica A, et al. Eye movement abnormalities in essential tremor. J Hum Kinet 2016;52:53-64.

10. Gitchel GT, Wetzel PA, Baron MS. Slowed saccades and increased square wave jerks in essential tremor. Tremor Other Hyperkinet Mov (N Y). 2013:3.

11. Helmchen C, Hagenow A, Miesner J, et al. Eye movement abnormalities in essential tremor may indicate cerebellar dysfunction. Brain 2003;126:13191332.

12. Trillenberg P, Führer J, Sprenger A, et al. Eye-hand coordination in essential tremor. Mov Disord 2006;21:373-379.

13. Çelebisoy M, Çelebisoy N, Ekinci AS, Akyüz E, Acarer A. Evaluation of Saccadic and Smooth Pursuit Eye Movements at an Early Stage of Essential Tremor. Journal of Neurological Sciences (Turkish) 2016;33:552-558.

14. Sengul Y, Sengul HS, Yucekaya SK, et al. Cognitive functions, fatigue, depression, anxiety, and sleep disturbances: assessment of nonmotor features in young patients with essential tremor. Acta Neurol Belg 2015;115:281 287

15. Louis ED. Linking Essential Tremor to the Cerebellum: Neuropathological Evidence. Cerebellum 2016;15:235-242.
16. Şaşığlu M, Gülol Ç, Tosun A. Alexithymia: Treatment Interventions. Current Approaches in Psychiatry 2014;6:22-31

17. Goerlich-Dobre KS, Votinov M, Habel U, Pripfl J, Lamm C. Neuroanatomica profiles of alexithymia dimensions and subtypes. Hum Brain Mapp 2015;36:3805-3818

18. Moriguchi Y, Decety J, Ohnishi T, et al. Empathy and judging other's pain: an fMRI study of alexithymia. Cereb Cortex 2007;17:2223-2234.

19. Louis ED, Ford B, Lee H, Andrews H, Cameron G . Diagnostic Criteria for Essential Tremor: A Population Perspective. Arch Neurol 1998;55:823-828.

20. Bagby RM, Parker JD, Taylor GJ . The twenty-item Toronto Alexithymia scale--I. Item selection and cross-validation of the factor structure. J Psychosom Res 1994;38:23-32.

21. Güleç H, Köse S, Güleç MY, et al. Reliability and Factorial Validity of the Turkish Version of the 20-Item Toronto Alexithymia Scale (TAS-20). Bulletin of Clinical Psychopharmacology 2009;19:214-220.

22. Salkind MR. Beck depression inventory in general practice. J R Coll Gen Pract 1969;18:267-271.

23. Piotrowski $\mathrm{C}$. The status of the beck anxiety inventory in contemporary research. Psychol Rep 1999;85:261-262.

24. Louis ED. The evolving definition of essential tremor: What are we dealing with? Parkinsonism Relat Disord 2018;46(Suppl 1):87-91.

25. Chunling W, Zheng X. Review on clinical update of essential tremor. Neurol Sci 2016;37:495-502.

26. Louis ED. Essential tremor as a neuropsychiatric disorder. J Neurol Sci 2010;289:144-148.

27. Thenganatt MA, Louis ED. Parkinsonism Personality profile in essential tremor: a case-control study. Parkinsonism Relat Disord 2012;18:10421044 .

28. Chatterjee A, Jurewicz EC, Applegate LM, Louis ED. Personality in essential tremor: further evidence of non-motor manifestations of the disease. J Neurol Neurosurg Psychiatry 2004;75:958-961.

29. Gasparini M, Bonifati V, Fabrizio E, et al. Frontal lobe dysfunction in essential tremor: a preliminary study. J Neurol 2001;248:399-402.

30. Lombardi WJ, Woolston DJ, Roberts JW, Gross RE. Cognitive deŞcits in patients with essential tremor. Neurology 2001;57:785-790.

31. Lacritz LH, Dewey R Jr, Giller C, Cullum CM. Cognitive functioning in individuals with "benign" essential tremor. J Int Neuropsychol Soc 2002;8:125-129.

32. Tröster AI, Woods SP, Fields JA, et al. Neuropsychological deŞcits in essential tremor: an expression of cerebello-thalamo-cortical pathophysiology? Eur J Neurol 2002;9:143-151.

33. Benito-Leon J, Louis ED, Bermejo-Pareja F; Neurological Disorders in Central Spain (NEDICES) Study Group. Population-based case-control study of cognitive function in essential tremor. Neurology 2006;66:69-74.

34. Sahin HA, Terzi M, Uc S, Yapici O, Basoglu T, Onar M. Frontal functions in young patients with essential tremor: a case comparison study. J Neuropsychiatry Clin Neurosci 2006;18:64-72.

35. Louis ED, Benito-León J, Bermejo-Pareja F; Neurological Disorders in Central Spain (NEDICES) Study Group. Self reported depression and antidepressant medication use in essential tremor: cross-sectional and prospective analyses in a population-based study. Eur J Neurol 2007;14:1138-1146.

36. Louis ED, Huey ED, Gerbin M, Viner AS. Depressive traits in essential tremor: impact on disability, quality of life, and medication adherence. Eur J Neurol 2012;19:1349-1354.

37. Chandran V, Pal PK. Quality of life and its determinants in essential tremor Parkinsonism Relat Disord 2013;19:62-65.

38. Benito-Leon J, Louis ED, Bermejo-Pareja F. Short sleep duration heralds essential tremor: a prospective, population-based study. Mov Disord 2013;28:1700-1707.

39. Sengul Y, Sengul H. Is it true that essential tremor affects sleep? A comparison between young essential tremor patients and normal controls. Sleep and Biological Rhythms 2015;13:309-315. 